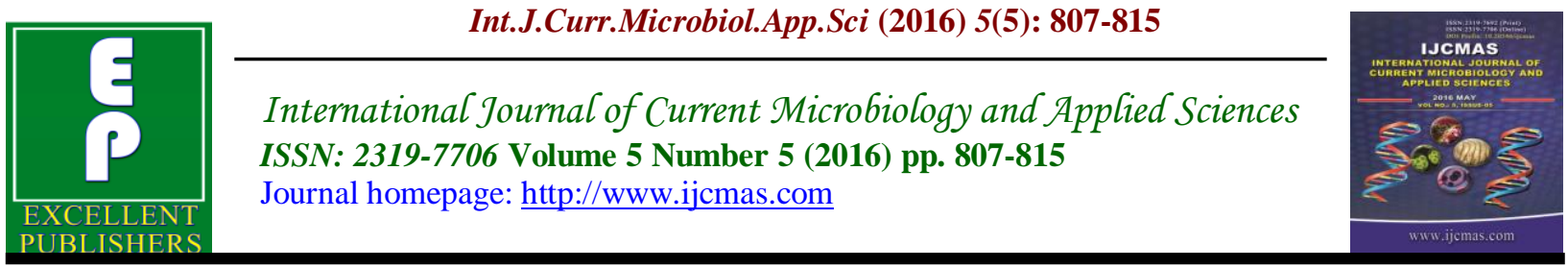

Review Article

http://dx.doi.org/10.20546/ijcmas.2016.505.081

\title{
Protease Production from Polyextremophilic Bacteria
}

\author{
Jyoti Sharma*, Nupur Mathur and Anuradha Singh \\ University of Rajasthan \\ *Corresponding author
}

\begin{tabular}{|c|}
\hline \\
\hline $\begin{array}{l}\text { K ey w o r d s } \\
\text { Extremophilic, } \\
\text { Polyextremophiles, } \\
\text { Proteases, } \\
\text { Industrial } \\
\text { sector }\end{array}$ \\
\hline Article Info \\
\hline $\begin{array}{l}\text { Accepted: } \\
20 \text { April } 2016 \\
\text { Available Online: } \\
10 \text { May } 2016\end{array}$ \\
\hline
\end{tabular}

\section{A B S T R A C T}

Extremophilic organisms which are capable of surviving in two different extreme environmental conditions simultaneously are known as polyextremophiles. These organisms are known to be potent producers of bioactive compounds namely enzymes such as proteases which are rapidly used in the growing industrial sector uses such as in the detergent industry, dairy industry, silver recovering, leather industry, etc. These polyextremophilic bacteria have not been explored much, only $2-5 \%$ of them are known, the rest remains to be discovered, thus we aim to isolate proteolytic enzymes from polyextremophiles since the isolated enzyme will be stable at more than one extreme condition, which would therefore be greatly employed in the industrial sector where these enzymes will be stable at different conditions simultaneously.

\section{Introduction}

Extremophiles are those groups of microorganisms that have evolved to exist in a variety of extreme environments where normal life is not possible. They may be unicellular or multicellular organisms which fall into different categories such as thermophiles, psychrophiles, halophiles, barophiles, acidophiles, alkaliphiles and others (Rothschild et al., 2001). In order to adapt in such harsh conditions of temperature, $\mathrm{pH}$, etc. microbes modify their cellular and molecular components and sustain well (Bertemont and Gerday, 2011).

Extremophiles are of wide industrial importance as a number of industrially active enzymes (amylases, proteases, lipases, cellulases, xylanases, etc.), secondary metabolites (antibiotics, phenols, alkaloids) and pigments are being produced by them which are of wide industrial importance, some examples of the biotechnological products derived from these extremophiles are given in Table 1 (Bertus van den Burg, 2003).

The extremophiles that can tolerate more than one factor of harsh conditions are called polyextremophiles. They have specialized cell wall architecture that makes them susceptible to more than one form of environmental stress, some common examples include thermoacidophiles, psychrohalophiles, thermoalkaliphiles, etc. However, only 2-5\% of these polyextremophilic bacteria have been explored, the rest are still in dark, these 
bacteria are known as producers of a great range of bioactive compounds (enzymes, antibiotics, pigments), thus they are a major area of research.

Polyextremophiles are the producers of industrially important enzymes such as Bacillus sp. which produces alkaline and serine proteases, amylases, pectinases, cellulases, lipases and xylanases (Martins et al., 2001).

Thus, polyextremophiles are a rich source of industrially important enzymes which are rapidly used to boost up the industrial sector and proteases being one of them. A number of polyextremophilic bacteria are known to survive in different extreme environmental conditions, some of the major types of polyextremophiles are described below.

\section{Types of Polyextremophiles}

The extremophiles that can tolerate more than one factor of harsh conditions are called polyextremophiles. They are unicellular or multicellular organisms that are present worldwide in different extreme environments where normal life is not possible i.e. they are found where others cannot survive. The polyextremophiles are divided into different categories depending on the habitats where they are found, some of them have been described in the text below.

Psychrohalophiles are readily found in environments where high saline conditions accompany cold atmospheres. These are found in habitats such as Arctic and Antarctic lakes and oceans. In India they are found mainly in the lakes of Jammu and Kashmir. A psychrophilic and slightly halophilic methanogen Methanococcoides burtonii was isolated from perennially cold, anoxic hypolimnion of Ace Lake, Antarctica (Franzmann et al., 1992).
Thermoacidophiles prefer temperatures of $70-80^{\circ} \mathrm{C}$ and $\mathrm{pH}$ between 2 and 3 . They live mostly in hot springs or within deep ocean vent communities. The most thermophilic of the extreme thermoacidophiles, Acidianus infernus, grows at temperatures up to $95^{\circ} \mathrm{C}$ but at $\mathrm{pH}$ as low as 1.0 (Huber et al., 2006). Furthermore, several new species in known genera of Sulfolobales (Acidianus, Metallosphaera) have also been reported, as well as a new member of the Thermoplasmatales, Thermogymnomonas acidicola have been reported (Yoshida et al., 2006; Itoh et al., 2007; Plumb et al., 2007 and Kozubal et al., 2008).

Recently, an extracellular thermostable acid protease from a thermoacidophilic archaeon Thermoplasma volcanium was discovered (Semra et al., 2007).

Haloalkaliphiles require both alkalinity $(\mathrm{pH}$ 9) and salinity up to saturation $33 \%$ (wt/vol) for survival (Horikoshi, 1999). Some of the common habitats of these haloalkalophiles are Wadi Natrun Lakes of Egypt, Lake Magadi in Kenya, and the Great Basin lakes of the western United States (Shiladitya et al., 2012). In India they are usually found in Lake Lonar. Some examples of haloalkalophiles include Natronobacterium magadii (Lodwick et al., 1994), Alcalilimnicola halodurans (Yakimov et al., 2001), etc.

Halothermophiles are defined as an organism requiring at least $1.5 \mathrm{M} \mathrm{NaCl}$ and a temperature at or above $50^{\circ} \mathrm{C}$ for optimal growth. Only a small number of halothermophiles have been validly described so far. Some of them are Haloarcula quadrata (Oren et al., 1999), Haloterrigena thermotolerans (MontalvoRodriguez et al., 2000), and Halobacterium salinarum (Grant, 2001). Habitats for these microorganisms include Great Salt Lake in 
the western United States and the Dead Sea in the Middle East.

Thermoalkaliphiles are a group of organisms which require both high temperatures as well as very high $\mathrm{pH}$ ranges. Few of them which have been recently discovered are Bacillus clausii (Kazan et al., 2005), Bacillus licheniformis (Olajuyigbe et al., 2005) and Bacillus circulans (Jaswal et al., 2007). They are found in various geothermally heated regions of the Earth, such as hot springs like those in Yellowstone National Park and deep sea hydrothermal vents. In India a great number of thermophiles can be extracted from arid and semiarid regions of Gujarat, Karnataka and Rajasthan.

Oligotroph is an organism that can live in environment that offers low levels of nutrients; they may be contrasted with copiotrophs, which prefer nutritionally rich environments. Pelagibacter ubique, which is the most important organism in the oceans and lichens with their extremely low metabolic rate. Lake Vostok in Antartica, sand plains and lateritic soils of South Western America and Indian Ocean are certain examples of oligotrophic habitats.

\section{Proteases}

Proteases (E.C.3.4.21.14) are those groups of hydrolytic enzymes that act on proteins and break them into peptides and amino acids, thus also known as proteolytic enzymes; they perform proteolysis by degradation of complex substances into simpler ones (Swapna et al., 2011). They are the most important industrial enzymes constituting upto $60-65 \%$ of world's total enzyme market (Woods et al., 2001) and are of great application in detergents, food processing, silk gumming, feather processing, food processing, pharmaceuticals, bioremediation, biosynthesis and biotransformation (Gupta et al., 2002; Bhaskar et al., 2007; Jellouli et al., 2009 and Sareen and Mishra, 2008).

Proteases are produced from different kinds of microorganisms; from bacteria (Najafi et al., 2005; Nadeem et al., 2009 and Pawar et al., 2009), fungi (Charles et al., 2008 and Sindhu et al., 2009), yeast (Chi et al., 2007) and actinomycetes (Thumar and Singh, 2007; Vonothini et al., 2008 and Vishalakshi et al., 2009) in addition to its production from plants (papain and ficin) and animals (trypsin and chymotrypsin). Some of the different types of proteases are described in Table 2.

A number of bacterial species have been found to produce proteases, these could be exploited on a commercial level to boost up the industrial sector, and some of the bacterial strains which produce protease have been mentioned in Table 3 .

\section{Industrial Uses of Proteases}

\section{Food and Feed Industry}

Proteases are often used for purposes such as cheese making, baking, preparation of soya hydrolysates, and meat tenderization. These enzymes are used to improve the extensibility and strength of the dough. Chymosin is usually preferred due to its high specificity for casein, which is responsible for its excellent performance in cheese making (Saraswathy et al., 2014).

\section{Leather Industry}

In leather industries, proteases are used to speed up the process of dahairing. Complete removal of hair has been achieved through enzymes without chemical assistance (Thangam et al., 2001; Dayanandana et al., 
2003 and Macedo et al., 2005). Similar findings about dehairing have also been reported with protease produced by a mutant strain of B. pumilus BA06 (Wang et al., 2007). The use of enzyme based leather dehairing technology has been considered as an environment friendly alternative to the conventional chemical process (Dayanandan et al., 2003; Arunachalam et al., 2009).

Table.1 Industrially Important Products Derived from Extremophiles.

\begin{tabular}{|c|c|}
\hline Thermophiles and Hyperthermophiles & Applications \\
\hline DNA polymerases & DNA amplification by PCR \\
\hline Lipases, pullulanases and proteases & Detergents \\
\hline Amylases & Baking and brewing \\
\hline Xylanases & Paper bleaching \\
\hline Halophiles & Applications \\
\hline Bacteriorhodopsin & \begin{tabular}{|l}
$\begin{array}{l}\text { Optical } \\
\text { photocurrent generators }\end{array}$ \\
\end{tabular} \\
\hline Lipids & Liposomes for drug delivery and cosmetics \\
\hline Compatible solutes e.g. Ectoin & Protein, DNA and cell protectants \\
\hline $\begin{array}{l}\text { g-Linoleic acid, b-carotene and cell } \\
\text { extracts,e.g. Spirulina and Dunaliella }\end{array}$ & \begin{tabular}{|lcc} 
Health foods, dietary & supplements, \\
food colouring and feedstock
\end{tabular} \\
\hline Psychrophiles & Applications \\
\hline Alkaline phosphatase & Molecular biology \\
\hline \begin{tabular}{llll|}
$\begin{array}{l}\text { Proteases, lipases, cellulases } \\
\text { amylases }\end{array}$ & and \\
\end{tabular} & Detergents \\
\hline Polyunsaturated fatty acids & Food additives, dietary supplements \\
\hline Ice nucleating proteins & Artificial snow, food industry e.g. ice cream \\
\hline Alkaliphiles and Acidophiles & Applications \\
\hline $\begin{array}{|lll|}\begin{array}{l}\text { Proteases, cellulases, lipases } \\
\text { pullulanases }\end{array} & & \\
\end{array}$ & Detergents \\
\hline Elastases, keritinases & Hide dehairing \\
\hline Cyclodextrins & Foodstuffs, chemicals and pharmaceuticals \\
\hline Acidophiles & \begin{tabular}{|llll}
$\begin{array}{l}\text { Fine papers, waste treatment and } \\
\text { degumming }\end{array}$ & & \\
\end{tabular} \\
\hline Sulphur oxidizing acidophiles & $\begin{array}{l}\text { Recovery of metals and desulphurication of } \\
\text { coal }\end{array}$ \\
\hline Acidophiles & Organic acids and solvents \\
\hline
\end{tabular}


Table.2 Types of Proteases

\begin{tabular}{|l|l|l|}
\hline Serine proteases & Uses a serine alcohol & $\begin{array}{l}\text { Trypsin, } \\
\text { Elastase, Proteinase Thrombin }\end{array}$ \\
\hline Threonine proteases & $\begin{array}{l}\text { Uses a threonine secondary } \\
\text { alcohol }\end{array}$ & Ornithine acetyltransferase \\
\hline Cysteine proteases & Uses a cysteine thiol & $\begin{array}{l}\text { Calpains, Cathepsins, Caspases, } \\
\text { Papain }\end{array}$ \\
\hline Aspartate proteases & Uses an aspartate carboxylic acid & Pepsin, Renin \\
\hline $\begin{array}{l}\text { Glutamic acid } \\
\text { proteases }\end{array}$ & Uses a glutamate carboxylic acid & Eqolisins \\
\hline Metalloproteases & Uses a metal ion & $\begin{array}{l}\text { Thermolysin, collagenase, } \\
\text { Carboxypeptidases }\end{array}$ \\
\hline
\end{tabular}

Table.3 Major Bacteria Producing Proteases

\begin{tabular}{|l|l|}
\hline Name of organism & References \\
\hline Streptomyces microflavus & Rifaat et al., (2006) \\
\hline Aspegillus clavutus & Hajji et al., (2007) \\
\hline Bacillus circulans & Jaswal et al., (2007) \\
\hline Salinivibrio sp. Strain AF-2004 & Heidari et al.,(2007) \\
\hline Lactobacillus helveticus & Valasaki et al., (2008) \\
\hline Thermophillic bacteria & Tyagi et al., (2008) \\
\hline Pseudomonas aeruginosa & Tang et al., (2010) \\
\hline Streptomyces isolate EGS-5 & Ahmad (2011) \\
\hline Gammaproteobacter & Fulzele et al., (2011) \\
\hline Bacillus licheniformis & Sathyavrathan et al., (2013) \\
\hline
\end{tabular}

\section{Medicinal Industry}

Microbial proteases are increasingly used in treatment of various disorders such as cancer, inflammation, cardiovascular disorders, necrotic wounds, etc (Chanalia $e t$ al.,2011). Proteases are also used an immunostimulants (Biziulenvicius, 2006). Proteases are used extensively in the pharmaceutical industry for preparation of medicines such as ointments for debridement of wounds. It is also used in denture cleaners and as contact-lens enzyme cleaners (Gupta et al., 2002)

\section{Detergent Industry}

Enzymes have been added to laundry detergents since last 50 years to facilitate the release of proteinaceous material in stains such as those of milk and blood. Proteases isolated from pseudomonas aerugenosa PD100 was used to remove blood stains from coton cloths in the absence of detergents (Najafi et al., 2005).they are also used to remove proteins from cloths spoiled with blood, meat, sweat,etc (Kumar et al.,2008).

\section{Silk Degumming}

Enzymatic degumming involves the proteolytic degradation of sericin. Enzymatic action modifies the surface of wool and silk fibres to provide them a new and unique finishing. The traditional process 
are generally expensive and therefore an alternative method suggested is the use of enzyme preparations, such as protease, for degumming the silk prior to dyein (Johnny et al.,2012).

\section{Silver Recovery}

Recovery of silver by burning the films causes environmental pollution and health risks. On the other hand, protease breaks the gelatin layer embedded with silver in films creating pollution free stripping. The amount of silver varies from $5-15 \mathrm{~g} / \mathrm{kg}$ of film. The enzymatic method although being slow is free from pollution and cost-effective too (Vaishali, 2013).

\section{Peptide Synthesis}

Recently the application of proteases in synthesis of oligopeptides has received great attention as an alternative to chemical approach (Ma et al., 2007; Wang et al., 2009). Proteases have been used successfully for the synthesis of dipeptides (Barros et al., 1999) and tripeptides (So et al., 2000).

\section{Proteases from Polyextremophiles}

We have recently discussed about the multiple applications of proteases in different industrial sectors, however, if an enzyme is designed to combat in a variety of conditions then that will prove as a boon for the industrial sector. A number of polyextremophiles have been identified in the last few years which are a rich source of industrially important enzymes and other secondary metabolites but a very little work has been done on protease production from polyextremophiles, thus they could be cultured and grown for isolation of proteases which are of industrial use.
In conclusion, they are the unique microorganisms, with great potential for microbiology and biotechnological exploitation. Proteases play a decisive role in detergent, pharmaceutical, leather, food and agricultural industries. However, only $10 \%$ of the polyextremophiles have been discovered, the rest remains to be discovered, they are of great industrial application and could be exploited in number of industries to boost up the industrial sector, thus a lot of work remains to be done on them. Properties of proteases such as alkaline $\mathrm{pH}$, thermostability, solvent and detergent resistance makes the enzyme very useful for various industrial applications. Thus it is desirable to search for new proteases with novel properties from as many extremophilic sources as possible.

A large number of proteases have already been discovered, but we are looking towards those proteolytic enzymes which can work simultaneously at two different conditions i.e., at high temperature and high $\mathrm{pH}$ (Thermoalkaliphiles), high temperature and low salt concentrations (Halothermophiles), etc.

Thus, these polyextremophiles which are capable of working at two different conditions are a novel source of industrial enzymes with potent industrial applications. Thus, the emphasis is towards isolation of proteases producing polyextremophiles which can act simultaneously under two different extreme conditions.

Looking into the commercial success of this enzyme class, researchers have now started aiming at the discovery and engineering of novel enzymes that are more robust with respect to their $\mathrm{pH}$ and temperature kinetics. Hence, although microbial proteases already play an important role in several industries, their potential is much greater and their 
applications in future processes are likely to increase in the near future.

\section{References}

Ahmad, S.M. (2011) Production of thermostable alkaline protease from an alkalineresistant Streptomyces isolate EGS5. International Journal of Academic Research, 3, 393.

Aurachalam C. and Saritha K. (2009) Protease enzyme: an eco-friendly alternative for leather industry. Indian Journal of Science and Technology. 2(12); 29-32.

Bertemont R. and Gerday C. (2011) The Extremophiles Comprehensive Biotechnology (Second Edition) 229-242.

Bertus van den Burg (2003) Extremophiles as a source for novel enzymes. Elsevier 6;213-218.

Bhaskar N., Sudeepa, E.S., Rashmi, H.N., Selvi, A.T., (2007). Partial purification and characterization of protease of Bacillus proteolyticus-CFR3001 isolated from fish processing waste and its antibacterial activities. Bioresour. Technol. 98; 27582764.

Biziulenvicius GA, (2006) Where do the immunostimulatory effects of oral proteolytic enzymes(systemic enzyme therapy) come from?Microbial proteolysisi as a possible starting point. Medical Hypotheses. 67(6) ;1386 - 1388.

Chanalia P., Gandhi D, Jodha D. Singh (2011) Applications of microbial proteases in pharmaceutical Industry:an over view. Rev Medical Microbial, 22(4) ;96-101.

Charles P, Devanathan V, Anbu P, Ponnuswamy M N, Kalaichelvan P T, Hur B K (2008) Purification, characterization and crystallization of an extracellular alkaline protease from Aspergillus nidulans HA10. J. Basic Microbiol. 48: 347-352.

Chi Z, Ma C, Wang P, Li H F (2007) Optimization of medium and cultivation conditions for alkaline protease production by the marine yeast Aureobasidium pullulans. Biores. Technol. 98: 534-538.
Franzmann P D, Springer N, Ludwig W, Conway de Macario E, Rohde M (1992) A methanogenic archaeon from Ace Lake, Antarctica: Methanococcoides burtonii sp. nov. Syst. Appl. Microbiol.15: 573581.

Fulzele R, Elisha D S, Yadav A, Shouche Y, Bhadekar R (2011). Characterization of novel extracellular protease produced by marine bacterial isolate from the Indian Ocean. Braz. J. Microbiol. 42: 1364-1373.

Grant W D, Kamekura M, McGenity T J, Ventosa A (2001). In DR Boone and RW Castenholz, eds. Bergey's Manual of Systematic Bacteriology Volume 1: The Archaea and the deeply branching and phototrophic Bacteria (2nd ed.). New York: Springer Verlag 169.

Gupta R, Beg QK and Chauhan B ( 2002) An overview on fermentation, downstream processing and properties of microbial proteases. Applied Microbiol Biotechnol 60; 381-395.

Gupta, R., Beg, Q.K., Lorenz, P., (2002). Bacterial alkaline proteases: molecular approaches and industrial applications. Appl. Microbiol. Biotechnol. 59; 15-32.

Heidari H R K, Ziaee A A, Schaller J, Amoozegar M A (2007) Purification and characterization of an extracellular haloalkaline protease produced by the moderately halophylic bacterium, Salinivibrio sp. strain AF-2004. Enz. Microbial Tech. 40: 266-272.

Horikoshi K (1971) Production of alkaline enzymes by alkalophilic microorganisms. Agric. Biol. Chem. 35: 1407-1414.

Huber H, and Prangishvili D (2006a)The Sulfolobales. In: Dworkin, M., Falkow, S., Rosenberg, E., Schleifer, K. and Stackebrandt, E. editors.. The Prokaryotes. 3. Springer; 23-50.

Itoh T, Yoshikawa N, Takashina T (2007). Thermogymnomonas acidicola gen. nov., sp. nov. a novel thermoacidophilic, cell wall-less archaeon in the order Thermoplasmatales, isolated from a solfataric soil in Hakone, Japan. Int. J. Syst. Evol. Microbiol. 57: 2557-2561.

Jaswal RK, Kocher GS (2007) Partial characterization of a crude alkaline 
protease from Bacillus circulans and its detergent compatibility. Int. J. Microbiol. 4(1): 1-5.

Jellouli, K., Bougatef, A., Manni, L., Agrebi, R., Siala, R., Younes, I., Nasri, M., (2009). Molecular and biochemical characterization of an extracellular serineprotease from Vibrio metschnikovii J1. J. Ind. Microbiol. Biotechnol. 36;939-948.

Kazan D, Denizci A A, Oner M N K, Erarslan A (2005) Purification and characteriztion of serine alkaline protease from Bacillus clausii GMBAE 42 J. Ind. Microb. Biotech. 32:335-344.

Kozubal M, Macur R E, Korf S, Taylor W P, Ackerman G G, Nagy A, Inskeep W P (2008) Isolation and distribution of a novel iron-oxidizing crenarchaeon from acidic geothermal springs in Yellowstone National Park. Appl. Environ. Microbiol. 4: 942-949.

Lynn J. Rothschild \& Rocco L. Mancinelli (2001) Life in extreme environments. Nature 409 ; 1092-1101.

Montalvo-Rodriguez R, Lopez-Garriga J, Vreeland R H, Oren A, Ventosa A, Kamekura M (2000). Haloterrigena thermotolerans sp. nov., a Halophilic Archaeon from Puerto Rico. Int. J. Syst. Evol. Micro. 50: 1065-1071.

Nadeem M, Qazi J I, Baig S (2009) Effect of aeration and agitation rates on alkaline protease production by Bacillus licheniformis UV-9 mutant. Turk J Biochem. 34 (2): 89-96.

Najafi M F, Deobagkars D, Deobagkar D (2005). Potential application of protease isolated from Pseudomonas aeruginosa PD100. Elect. J. Biotechnol. 8: 197-203.

Olajuyigbe F M, Ajele J O (2005) Production dynamics of extracellular protease from Bacillus sp. Afr. J. Biotechnol. 4: 776779.

Oren A (1999) Bioenergetic Aspects of Halophilism. Microbiol. Mol. Biol. Rev. 63: 334-348.

Pawar R, Zambare V, Barve S, Paratkar G (2009) Application of protease isolated from Bacillus sp. 158 in enzymatic cleansing of contact lenses. Biotechnol. 8: 276-280.
Plumb J J, Haddad C M, Gibson J A, Franzmann P D (2007). Acidianus sulfidivorans sp. nov. an extremely acidophilic, thermophilic archaeon isolated from a solfatara on Lihir Island, Papua New Guinea, and emendation of the genus description. Int. J. Syst. Evol. Microbiol. 57: 1418-1423.

Rakesh Kumar, Ritika Vats (2010)Protease production by Bacillus subtilis Immobilized on Different Matrices. New York Science Journal. 3(7) ;20-24.

Rifaat H M, Hassanein S M, El-Said O H, Saleh S M, Selim M S M (2006) Purification and characterisation of extracellular neutral protease from Streptomyces microflavus. Arab J. Biotechnol. 9: 51-60.

Rinsey Johnny, V.A. \& Karpagam Chinnammal, S.(2012) Degumming of silk using protease enzyme from bacillus species. International journal of science and nature.. 3(1); 51-59

Sareen, R., Mishra, P., (2008). Purification and characterization of organic solvent stable protease from Bacillus licheniformis RSP09-37. Appl. Microbiol. Biotechnol. 79; 399-405.

Sathyavrathan P, Krithika S (2013) Production and Optimization of Protease from Bacillus licheniformis NRRL-NRS-1264 using cheap source substrates by submerged $(\mathrm{SmF})$ and solid-state fermentation (SSF) Int. J. Chem Tech Res. 6: 286-292.

Semra KocabÂyÂk , Hatice Özel (2007) An extracellular Pepstatin insensitive acid protease produced by Thermoplasma volcanium. Bioresource Technology. 98; 112-117.

Shiladitya DasSarma, Priya DasSarma (2012) Halophiles.Wiley. 1-11

Sindhu R, Suprabha G N, Shashidhar S (2009) Optimization of process parameters for the production of alkaline protease from Penicillium godlewskii SBSS 25 and its application in detergent industry. Afr. J. Microbiol. Res. 3(9): 515-522.

Swapna Vadlamani, Sreenivasa Rao Parcha, (2011) Studies on industrially important alkaline protease production from locally isolated superior microbial strain from 
soil microorganisms, International Journal of Biotechnology Applications. 3 (3); 102- 105.

Tang X Y, Wu B, Ying H J, He B F (2010) Biochemical properties and potential application of a solvent stable protease from the high-yield protease producer Pseudomonas aeruginosa PT 121. Appl. Biochem. Biotechnol.160: 1017-1031.

Thumar J T, Singh S P (2007) Secretion of an alkaline protease from a salt-tolerant and alkaliphilic, Streptomyces clavuligerus strain MIT-1. Brazil. J. Microbiol. 38: 766-772.

Vaishali Choudhary(2013) Recovery of Silver from used X-ray films by Aspergillus versicolor protease. Journal of Academia and Industrial Research, 2(1);39-41.

Valasaki K, Staikou A, Theodorou L G, Charamopoulou V, Zacharaki P, Papamichael E M (2008). Purification and kinetics of two novel thermophilic extracellular proteases from Lactobacillus helveticus, from kefir with possible biotechnological interest. Bio. Tech. 99: 5804-5813.

Vishalakshi N, Lingappa K, Amina S, Prabhakar M, Dayanand A (2009) Production of alkaline protease from Streptomyces gulbargensis and its application in removal of blood stain. Ind. J. Biotechnol. 8: $280-285$.

Vonothini G, Murugan M, Sivakumar K, Sudha $S$ (2008) Optimization of protease production by an actinomycete Strain, PS18A isolated from an estuarine shrimp pond. Afr. J. Biotechnol. 7(18): 32253230.

Woods R.G, Burger M, Beven C A, Beacham I $\mathrm{R}$ (2001) TheaprX-lipA operon of Pseudomonas fluorescens B52: a molecular analysis of metalloprotease and lipase production. Microbiology. 147: 345-354.

Yakimov M M, Giuliano L, Chemikova T N, Gentile G, Abraham W R, Lunsdorf H, Timmis K N, Golyshin P N (2001) Alcalilimnicola halodurans gen. nov., sp. nov., an alkaliphilic, moderately halophilic and extremely halotolerant bacterium, isolated from sediments of soda-depositing Lake Natron, East Africa Rift Valley. Int. J. Syst. Evol. Microbiol. 51: 2133-2143.

\section{How to cite this article:}

Jyoti Sharma, Nupur Mathur and Anuradha Singh.2016. Protease Production from Polyextremophilic Bacteria. Int.J.Curr.Microbiol.App.Sci.5(5): 807-815. doi: http://dx.doi.org/10.20546/ijcmas.2016.505.081 